\title{
The Effect of Show and Tell Method on Children's Confidence
}

\author{
Mallevi Agustin Ningrum \\ Department of Early Childhood Education \\ Universitas Negeri Surabaya, Indonesia \\ malleviningrum@unesa.ac.id
}

\author{
Muhammad Reza \\ Department of Early Childhood Education \\ Universitas Negeri Surabaya, Indonesia \\ muhammadreza@unesa.ac.id
}

\author{
Eka Cahya Maulidiyah \\ Department of Early Childhood Education \\ Universitas Negeri Surabaya, Indonesia \\ ekamaulidiyah@unesa.ac.id
}

\begin{abstract}
This study aims to determine the effect of show and tell method on self-confidence for students aged 45 years. This quantitative research uses Pre-Experimental Design with One Group Pre-Test Post-Test. The subjects were 25 children aged 4-5 years. Data were collected using observation along with its assessment tools, the observation sheets and documentation. Data were analyzed using Wilcoxon Match Pairs Test, $\mathrm{t}_{\text {observed }}<\mathrm{t}_{\text {table. }}$ The result showed that $t_{\text {observed }}$ was -7.5 and table was 89 with a significance level of $5 \%$, meaning that Ho is rejected and $\mathrm{Ha}$ is accepted. Therefore, it can be concluded that there is a significant effect of the show and tell method on the confidence of children aged 4-5 years.
\end{abstract}

Keywords: show and tell method, self-confidence, children aged 4-5 years

\section{INTRODUCTION}

Children have different characters from adults. They are always active, egocentric, unique, and have a great curiosity, as well as like to imagine. Children are unique figures who need help to develop their potential. To develop children's potential, an institution is needed to help children reach their developmental stages by stimulating appropriate learning activities to children's characteristics. Early childhood education is unit of education before primary education to provide guidance for children from birth until the age of six years through educational stimuli. This aims to prepare their physical and spiritual growth and development before having formal, non-formal, and informal institution [8]

Early childhood education plays a very important and decisive role in the history of children development because it is the foundation for the children's personality. Early childhood is child age 0 to 6 years. Early childhood are the children whose growth and development still grow rapidly, also called as developmental leap [3]. At the age of 0-6 years, children experience a sensitive period called the golden age. This period, children can develop cognitive skill, social emotional, moral religion, language, motor and arts optimally. Therefore, the appropriate stimulation is needed to achieve optimal growth and not delay in their development stage.

One aspect of development dealing with emotion control and socialization is emotional social development. Social and emotional development are two different aspects, but basically these two aspects affect each other. The habit of behaving and being kind is one way to develop children's emotional social behavior. The appropriate social and emotional behavior in directing children's personality should be in line with values in the community. Social and emotional behavior expected from early childhood are good behaviors, such as discipline, independence, responsibility, confidence, honesty, fairness, loyal friends, compassion towards others, and have a high tolerance [7].

Self-confidence is one of social and emotional behaviors important for children's lives. For children, having self-confidence help them to overcome every challenge and problem of life later [5]. If they do not have confidence then they cannot solve every problem. Selfconfidence must be owned by every child to live their lives because it will affect their mental development and character. The good mental and strong character is the important capital for their future in their adulthood, so that they can overcome every problem and challenge more realistically.

Erikson states that at the age of 4-5 years the children enter the first psychosocial stage in their life, and confidence involves physical comfort and no fear or anxiety about the future. children's self-confidence can be seen through their inner state and birth. The function and role of self-confidence is very important for life. Therefore, every teacher needs to instill confidence in children from an early age. Without being equipped with a strong self-confidence, a child will grow into a weak person [5].

According to Auerbach, one of 4-year-old children's skills on emotional social behavior is being confident to do everything themselves, but what happened is not as expected [7]. Based on the results of preliminary observations for 5 days with Group A2 teachers at Muslimat NU 82 Sambisari, Sidoarjo, East Java, Indonesia showed that there were still 18 of 25 children who was not able to show their confidence. It was proven by the absence of questions asked by children when learning because there was no opportunity for them to ask their teacher. Raising their hand, when the teacher asked them to answer questions, but some of them were still shy 
in answering even silent. In addition, when the teacher asked one of them to come forward leading the prayer, the child was embarrassed and some even did not want to. The learning process seemed monotonous (the song used) so that there were some children who ignored the teacher because he was not interested.

Teacher can help children's confidence using various methods in delivering material to achieve goals [1]. The methods used in learning at TK Sambatari Muslimat $82 \mathrm{NU}$ were demonstration, the question and answer, and assignment. The method used in kindergarten was unable to increase children's confidence. Thus, one method that could be used to increase children's confidence is the show and tell method.

The show and tell method are used to express children's skills, feelings and desires [8]. through understanding of their favorite object, children were interested in showing the object to friends and tell them about the toys they liked and indirectly made children confident to show in front of the class. The show and tell method are an interesting method applied in learning because this creates a fun and interesting learning atmosphere for children.

The show and tell method are a method to show objects that children know and tell them in front of the class in turn. The types of show and tell applied are show and tell using personal objects, favorite foods, and photos / images. Personal items owned by children, for example, children's toys, dolls they like, or other objects they like. The show and tell method are aimed to train children's language skills and also support the growth of selfconfidence. as stated by Patsalides, one of the benefits of the show and tell method is to increase children's selfconfidence [4].

In addition, the interesting methods, joyful atmosphere also supports the growth of children's selfconfidence. using music can help create it because music is emotional language that can affect one's heart. music is used to express or change moods that affects children's mood and behavior [9]. Music for children is an easy means to capture the information received and makes them happy. The show and tell method accompanied by music is a combination of showing and telling method to stimulate the growth of 4 to 5-year-old children's selfconfidence. The show and tell method give children the opportunity to be brave to show what they have and tell their friends. Musical accompaniment will create joyful and interesting learning atmosphere for children and can change their mood to be happy.

\section{METHODS}

This study used Pre-Experimental Design with One Group Pretest and Post-test Design. There were only experimental groups (given treatment) in this study. The populations were nine boys and sixteen girls of 25 children of group A2 in TK Muslimat NU 82 Sambisari Sidoarjo. This study used saturated sampling as a sampling technique. Data were collected using observation and documentation. The type of observation used was non-participant observation, where the researcher was not involved in learning activities but focused on the treatment and its results.
The documentations were photos of children's activities during pre-test, treatment, and post-test, daily lesson plan, and a list of children's names, to support the competence of data. The sample used was $n=25$ to obtain ordinal data and the sample was less than 30 children. The statistics in this study was nonparametric statistics using the Wilcoxon Match Pairs Test statistical test. The analysis of the Wilcoxon Match Pairs Test was used to test the significance of the comparative hypothesis of two correlated samples if the data are ordinal. When testing the hypothesis, writers used helper tables [6].

\section{III.RESULTS AND DISCUSSION}

This research was conducted in 3 stages, namely pre-test, treatment and post-test. The results of the pre-test showed that the children's confidence was still low. The results before the treatment (pre-test) was 187 with an average of 7.48 and the average for each item was 2.4 rounded to 2 and showed that confidence in A2 group children in TK Muslimat NU 82 Sambisari Sidoarjo was included in developing category.

The treatment conducted after pretest activities used the show and tell method accompanied by music during three meetings. In treatment 1 , the day before teacher asked the children to bring a family photo to share with their friends. The activity was begun with gymnastic then kept a good march while singing. Before starting the activity, the children did pray and singing. Then the teacher asked questions about theme of day. Before the teacher divided the children into three groups, they were invited to sing a song about the family it creates happy mood and joyful atmosphere.

After that children were asked to show and tell their family photos accompanied by music in turn. Here, the students as audience could give questions to children who were telling stories. When no one were initiative to move forward, the teacher sang song to motivate the child to go forward to tell stories and show. The next activity, the children had a break to eat and drink and then teacher invited the children to clean up the equipment and preparations to go home. The teacher gave questions and answers about today's activities. after that, the teacher invited children to sing the song "My Family" and prepare to go home by praying after the activity.

The procedure for treatment 2 and 3 was the same as treatment 1 . The difference was on the object brought by the children. In treatment 2 was favorite toys that the song sung was titled "Toys of passions". In treatment 3 was favorite food that the song sung was titled "Healthy Food". The activity ended with having meal together.

After the treatment finished, a post-test is was done like pre-test that was telling stories using pictures with the theme. The theme of the day was plants, with a sub-theme of trees. The results obtained after the treatment (post-test) showed that the total score obtained was 260 with an average of 10.4 and the average for each item was 3.4 rounded up to 3 so that the confidence of A2 group children included in developing category as expected.

The data from preliminary observation (pre-test) and final observation (post-test) on the effect of show and tell method accompanied by music on confidence of 25 
A2 group children in TK Muslimat NU 82 Sambisari Sidoarjo, was analyzed using nonparametric statistics using a level test marked Wilcoxon (Wilcoxon Match Pairs Test). The reason for using the Wilcoxon Match Pairs Test formula was to look for difference of group A children's skill in TK Muslimat NU 82 Sambisari Sidoarjo in terms of confidence before and after treatment using the show and tell method accompanied by music. In the Wilcoxon test, the difference between the number of positive and negative was calculated because the sample used in this study was 25 children, less than 30 children. the Wilcoxon test used a helper Table 1.

Table 1

Wilcoxon Helper Table

\begin{tabular}{|c|c|c|c|c|c|c|}
\hline \multirow[b]{2}{*}{ No } & \multirow{2}{*}{$\begin{array}{c}\text { Score } \\
\text { of } \\
\text { Pre- } \\
\text { test } \\
\left(\mathbf{X}_{\mathrm{A1}}\right) \\
\end{array}$} & \multirow{2}{*}{$\begin{array}{c}\text { Score } \\
\text { of } \\
\text { Post- } \\
\text { test } \\
\left(\mathrm{X}_{\mathrm{B} 1}\right)\end{array}$} & \multirow{2}{*}{$\begin{array}{c}\begin{array}{c}\text { Differ } \\
\text { ence }\end{array} \\
\mathbf{X}_{\mathrm{B} 1-} \\
\mathbf{X}_{\mathrm{A1}}\end{array}$} & \multicolumn{3}{|c|}{ Level } \\
\hline & & & & Level & + & - \\
\hline 1 & 7 & 11 & +4 & 16 & 16 & \\
\hline 2 & 9 & 12 & +3 & 7,5 & 7,5 & \\
\hline 3 & 8 & 12 & +4 & 16 & 16 & \\
\hline 4 & 6 & 10 & +4 & 16 & 16 & \\
\hline 5 & 9 & 11 & +2 & 3 & 3 & \\
\hline 6 & 5 & 9 & +4 & 16 & 16 & \\
\hline 7 & 6 & 10 & +4 & 16 & 16 & \\
\hline 8 & 6 & 11 & +5 & 22,5 & 22,5 & \\
\hline 9 & 9 & 9 & 0 & & & \\
\hline 10 & 9 & 11 & +2 & 3 & 3 & \\
\hline 11 & 8 & 11 & +3 & 7,5 & 7,5 & \\
\hline 12 & 7 & 10 & +3 & 7,5 & 7,5 & \\
\hline 13 & 6 & 10 & +4 & 16 & 16 & \\
\hline 14 & 9 & 10 & +1 & 1 & 1 & \\
\hline 15 & 6 & 10 & +4 & 16 & 16 & \\
\hline 16 & 10 & 12 & +2 & 3 & 3 & \\
\hline 17 & 6 & 10 & +4 & 16 & 16 & \\
\hline 18 & 9 & 12 & +3 & 7,5 & 7,5 & \\
\hline 19 & 8 & 12 & +4 & 16 & 16 & \\
\hline 20 & 5 & 9 & +4 & 16 & 16 & \\
\hline 21 & 7 & 10 & +3 & 7,5 & 7,5 & \\
\hline 22 & 3 & 8 & +5 & 22,5 & 22,5 & \\
\hline 23 & 8 & 12 & +4 & 16 & 16 & \\
\hline 24 & 9 & 6 & -3 & 7,5 & & 7,5 \\
\hline 25 & 12 & 12 & 0 & & & \\
\hline \multicolumn{5}{|c|}{ Total } & $\begin{array}{c}T+= \\
268,5\end{array}$ & $\begin{array}{l}\text { T- }= \\
-7,5\end{array}$ \\
\hline
\end{tabular}

The table above showed that $t_{\text {observed }}$ was -7.5 taken from the number of relatively small score without regarding to $\mathrm{t}_{\text {table }}$ by determining $(\mathrm{n}, \alpha)$, where $\mathrm{n}=$ samples were 25 children, while $\alpha=$ significance level was $5 \%(0.05)$ that $t_{\text {table }}$ was 89 . The result of $t_{\text {table }}$ obtained was 46 , or $\mathrm{t}_{\text {observed }}<\mathrm{t}_{\text {table }}(-7.5<89)$ [6]. Pretest and posttest result showed that children's self-confidence at group A2, TK Muslimat NU 82 Sambisari Sidoarjo as an experimental group. The pre-test score was 187 and post-test score was 260 (increasing). The result analyzed using Wilcoxon Match Pairs Test, $\mathrm{t}_{\text {observed }}<\mathrm{t}_{\text {table }}$ showed that $t_{\text {observed }}$ was -7.5 and table was 89 with a significance level of $5 \%$, or $t_{\text {observed }}<t_{\text {table }}$ was $-7.5<89$ that meant hat Ho was rejected and $\mathrm{Ha}$ is accepted.

Therefore, it can be concluded that there is effect of show and tell method accompanied by music on children's confidence in group A, TK Muslimat NU 82 Sambisari Sidoarjo. According to Petsalides, the benefit of show and tell method is to increase self-confidence [4]. The children aged four to five years should be fully confident with their own skill in doing everything [7]. Children are said to have high confidence if they are active but not excessive and not easily influenced by others [5].

\section{CONCLUSION}

The result showed that $t_{\text {observed }}$ was -7.5 and $t_{\text {table }}$ was 89 with a significance level of $5 \%$, meaning that Ho is rejected and $\mathrm{Ha}$ is accepted. Therefore, it can be concluded that there is a significant effect of the show and tell method on the confidence of children aged 4-5 years.

\section{REFERENCES}

[1] Fadlillah, M., Lilif Muallifatul Khorida F., Wantini, Eliyyil Akbar, \& Syifa Fauziyah. 2014. Edutaiment Pendidikan Anak Usia Dini (Menciptakan Pembelajaran Menarik, Kreatif, dan Menyenangkan). Jakarta: Kencana Prenada Media Group.

[2] Hasan, Maimunah. 2009. Pendidikan Anak Usia Dini Jakarta: Diva Press.

[3] Mulyasa. 2012. Manajemen Pendidikan Anak Usia Dini. Bandung: PT Remaja Rosdakarya.

[4] Musfiroh, Takdiroatun. 2011. Show And Tell Edukatif Untuk Pengembangan Empati, Afiliasi-Resolusi Konflik, Dan Kebiasaan Positif Anak Usia Dini. Jurnal Kependidikan, 41(2), 129-143.

[5] Rahayu, Aprianti Yofita. 2013. Menumbuhkan Kepercayaan Diri Melalui Kegiatan Bercerita. Jakarta Barat: PT INDEKS.

[6] Sugiyono. 2015. Metode Penelitian Pendidikan Pendekatan Kuantitatif, Kualitatif, dan R\&D. Bandung: Alfabeta.

[7] Susanto, Ahmad. 2011. Perkembangan Anak Usia Dini: Pengantar dalamBerbagai Aspeknya. Jakarta: Kencana Prenada Media Group.

[8] Suyanto, Slamet. 2005. Pembelajaran untuk Anak TK. Jakarta: Departemen Pendidikan Nasional.

[9] Santosa, Elizabeth. 2015. Raising Children in Digital Area (Pola Asuh Efektif untuk Anak di Era Digital. Jakarta: PT Elex Media Komputindo. 